This document is the accepted manuscript version of the following article:

Wang, W., English, N. B., Grossiord, C., Gessler, A., Das, A. J., Stephenson, N. L.,

Baisan, C. H., A7len, C. D., \& McDowe11, N. G. (2020). Mortality predispositions of

conifers across western USA. New Phytologist. https://doi.org/10.1111/nph.16864

DR WENZHI WANG (Orcid ID : 0000-0003-4574-409X)

DR CHARLOTTE GROSSIORD (Orcid ID : 0000-0002-9113-3671)

PROF. ARTHUR GESSLER (Orcid ID : 0000-0002-1910-9589)

Article type : Regular Manuscript

\title{
Mortality predispositions of conifers across Western USA
}

Wenzhi Wang ${ }^{1,2 *}$, Nathan B. English ${ }^{3}$, Charlotte Grossiord ${ }^{4,5}$, Arthur Gessler 4,6 , Adrian J. Das 7 , Nathan L. Stephenson ${ }^{7}$, Christopher H. Baisan ${ }^{8}$, Craig D. Allen ${ }^{9}$ Nate G. McDowell ${ }^{1}$,

1. Atmospheric Sciences and Global Change Division, Pacific Northwest National Laboratory, Richland, WA, 99352, USA

2. The Key Laboratory of Mountain Environment Evolution and Regulation, Institute of Mountain Hazards and Environment, Chinese Academy of Sciences, Chengdu 610041, China

3. School of Health, Medical and Applied Science, Central Queensland University, Townsville, QLD, 4810, Australia

4 Functional Plant Ecology, Community Ecology Unit, Swiss Federal Institute for Forest, Snow and Landscape WSL, Lausanne CH-1015, Switzerland.

5 Plant Ecology Research Laboratory PERL, School of Architecture, Civil and Environmental Engineering, EPFL, Lausanne CH-1015, Switzerland

6. Institute of Terrestrial Ecosystems, ETH Zurich, Universitaetsstrasse 16, 8092 Zurich, Switzerland

7. U.S. Geological Survey, Western Ecological Research Center, Three Rivers, CA 93271, USA 
8. Laboratory of Tree-Ring Research, University of Arizona, Tucson, AZ 85721, USA

9. U.S. Geological Survey, Fort Collins Science Center, New Mexico Landscapes Field Station, Los Alamos, NM 87544, USA

10. School of Biological Sciences, Washington State University, Pullman, WA 99164-4236, USA

*Corresponding author: Wenzhi Wang, wenzhi.wang@pnnl.gov, tel.: +1 509375 2602. Address: 902 Battelle Boulevard, Richland, WA 99352.

Received: 19 March 2020

Accepted: 4 August 2020

\section{ORCID ID:}

Wenzhi Wang: https://orcid.org/0000-0003-4574-409X

Nathan B. English: https://orcid.org/0000-0002-6936-8079

Charlotte Grossiord: https://orcid.org/0000-0002-9113-3671

Arthur Gessler: https://orcid.org/0000-0002-1910-9589

Nathan L. Stephenson: https://orcid.org/0000-0003-0208-7229

Craig D. Allen: https://orcid.org/0000-0002-8777-5989

\section{Summary:}

- Conifer mortality rates are increasing in western North America, but the physiological mechanisms underlying this trend are not well understood. 
- We examined tree-ring based radial growth along with stable carbon and oxygen isotope composition ( $\delta^{13} \mathrm{C}$ and $\delta^{18} \mathrm{O}$, respectively) of dying and surviving conifers at eight old-growth forest sites across a strong moisture gradient in the western USA to retrospectively investigate mortality predispositions.

- Compared to surviving trees, lower growth of dying trees was detected at least one decade prior to mortality at seven of the eight sites. Intrinsic water-use efficiency (iWUE) increased over time in both dying and surviving trees, with a weaker increase in dying trees at five of the eight sites.

- Carbon starvation was a strong correlate of conifer mortality based on a conceptual model incorporating growth, $\delta^{13} \mathrm{C}$, and $\delta^{18} \mathrm{O}$. However, this approach does not capture processes that occur in the final months of survival. Ultimately carbon starvation may lead to increased mortality vulnerability, but hydraulic failure or biotic attack may dominate the process during the end-stages of mortality in these conifers.

Keywords: Tree mortality, tree growth, stable carbon and oxygen isotope, water-use efficiency, carbon starvation, western USA conifers.

This article is protected by copyright. All rights reserved 


\section{Introduction}

Climate-driven tree mortality from rising temperature, vapor pressure deficit (VPD), drought and insect outbreaks is occurring globally (Allen et al., 2010; Hartmann et al., 2018; McDowell et al., 2018). This phenomenon is particularly severe for conifers across western USA, where the tree mortality rates increased significantly in the past four decades (van Mantgem et al., 2009). The physiological mechanisms of climate-induced tree mortality are not well understood, but can include physiological changes promoting hydraulic failure, carbon starvation, and biotic attack (McDowell et al., 2011; Das et al., 2016; Choat et al., 2018). Rising temperature and VPD coupled with soil drought forces lower growth and higher mortality in conifers (Williams et al., 2013) due to increased water loss that can promote hydraulic failure (Choat et al., 2018), and/or via greater stomatal closure to avoid water loss, which can promote carbon starvation (Adams et al., 2017). Despite growing research interest, the physiological mechanisms of conifer mortality, particularly over multi-year periods, is still not clearly documented, which limits our ability to mechanistically predict tree mortality globally (McDowell et al., 2016).

Trees are long-lived species and mortality mechanisms involve complex legacy effects (Manion, 1981; Anderegg et al., 2013; Anderegg et al., 2015). Tree radial growth, inferred from treering width data, provides retrospective information about carbon allocation to stemwood through trees' entire lifespans (Camarero et al., 2015; Cailleret et al., 2017). Tree rings have been used extensively to investigate growth patterns during the years prior to mortality (Christiansen et al., 1987; Waring, 1987; McDowell et al., 2010; Cailleret et al., 2017). Compiling from 2970 dying and 4224 surviving trees across 190 sites globally revealed $84 \%$ of the trees experienced a decrease in radial growth before death, with the duration of growth reductions varying from 1 year to 100 years (Cailleret et al., 2017). Moreover, a general increase in inter-annual growth variability was detected during the last 20 years before tree mortality in global gymnosperms, suggesting reduced resilience to environmental extremes (Cailleret et al., 2018).

As tree growth data alone are not adequate to inform on physiological mechanisms of tree mortality, stable isotope composition in tree rings can potentially provide additional retrospective insights into ecophysiological processes related to a tree's death (Gessler et al., 2014; Gessler et al., 
2018). Annually-dateable tree-ring stable carbon isotope composition $\left(\delta^{13} \mathrm{C}\right)$ are directly related to $\mathrm{CO}_{2}$ uptake and water balance, which generally reflects the trade-off of assimilation-weighted, crownscale photosynthesis rate $(A)$ and stomatal conductance $\left(\mathrm{g}_{\mathrm{s}}\right) \cdot \delta^{13} \mathrm{C}$ yields estimates of carbon isotope discrimination $(\Delta)$, intercellular $\mathrm{CO}_{2}$ concentration $\left(C_{\mathrm{i}}\right)$, and intrinsic water-use efficiency (iWUE) (Farquhar et al., 1989; McCarroll \& Loader, 2004; Seibt et al., 2008). Thus, $\delta^{13} \mathrm{C}$ of tree rings allows us to examine if trees that die experienced greater water stress (e.g. lower $\Delta$ ) or shifts in iWUE prior to mortality. Tree-ring stable oxygen isotope composition $\left(\delta^{18} \mathrm{O}\right)$ is influenced by the $\delta^{18} \mathrm{O}$ of precipitation, atmospheric humidity, and transpiration, as well as oxygen atom exchange processes at the leaf and xylem levels (Barbour, 2007; Gessler et al., 2014). $\delta^{18} \mathrm{O}$ of stem xylem is not related to $A$ (Roden et al., 2000) but shows a close relationship with $g_{s}$ either via a joint influence of VPD or via transpirational dilution of evaporatively enriched leaf water (Gessler et al., 2009) and, theoretically, can be applied to distinguish the effects of $A$ and $\mathrm{g}_{\mathrm{s}}$ on changes in $\Delta$ (Scheidegger et al., 2000; Roden $\&$ Siegwolf, 2012). Multi-proxy tree ring records (growth, $\delta^{13} \mathrm{C}, \delta^{18} \mathrm{O}$ ) have been recently used to understand long-term trends in iWUE (Guerrieri et al., 2019) and survival (Giguère-Croteau et al., 2019), and several studies have used multi-proxy tree-ring records to assess tree mortality mechanisms of individual species or site (Voltas et al., 2013; Hentschel et al., 2014; Gaylord et al., 2015; Colangelo et al., 2017). A conceptual framework combining long-term growth and isotope data was developed to identify the predisposition to hydraulic failure (fast or even no growth decline with high $A$ or high $\mathrm{g}_{\mathrm{s}}$ ) or to carbon starvation (slow or continuous growth decline with low $A$ or low $\mathrm{g}_{\mathrm{s}}$, Gessler et al., 2018). However, no studies, to our knowledge, have combined tree growth, iWUE and $\delta^{18} \mathrm{O}$ to investigate conifer physiological predispositions to mortality across a wide range of species and climates.

We developed a tree-ring multiproxy dataset of growth, $\delta^{13} \mathrm{C}$, and $\delta^{18} \mathrm{O}$ from eight undisturbed old-growth conifer forests in western USA. The eight sites spanned a broad range of climate conditions from the Pacific Northwest to Southwestern USA and all demonstrated increasing mortality trends over recent decades (van Mantgem et al., 2009). At each site, we compared surviving and dying trees to investigate the trajectories of whole-crown, assimilation-weighted gas exchange (from tree-ring $\delta^{13} \mathrm{C}$ and $\delta^{18} \mathrm{O}$ ) and growth prior to mortality, with the goal of detecting the physiological predispositions associated with tree mortality. We compared the difference of dying and 
surviving tree growth, iWUE and $\delta^{18} \mathrm{O}$ to identify the growth pattern and gas-exchange predispositions prior to tree mortality. We also assessed the resilience difference of dying and surviving tree growth, $\Delta$ and their response to growing season VPD. Using these data within the dualisotope approach conceptual framework (Gessler et al., 2018), we additionally investigated the evidence for contributions of carbon starvation and hydraulic failure to tree mortality. We tested two hypotheses regarding the physiological predispositions of tree mortality: (1) dying trees experienced consistent multi-year reductions in radial growth and increases in inter-annual variability compared to neighboring living congeners; and (2) iWUE of dying trees would be greater than that of surviving trees, reflecting more extreme water stress in the dying trees.

\section{Materials and Methods}

\section{Study region}

All sampling was performed in western USA (Fig. S1). The study area includes two predominant climate systems, with the Pacific Northwest and California influenced by a Mediterranean climate, and the Southwest dominated by the North American monsoon. Annual precipitation exhibits a substantial gradient, ranging from $3988 \mathrm{~mm}$ in the Pacific Northwest to 461 $\mathrm{mm}$ in the Southwest during the period 1975 to 2009, while annually averaged VPD ranges from 0.38 $\mathrm{kPa}$ in the Pacific Northwest to $0.97 \mathrm{kPa}$ in the Southwest. Though the climate types are different, temperature and drought have risen significantly in all of the western USA (Karl et al., 2009). All selected sites have old-growth conifer forests that have experienced increasing rates of tree mortality thought to be driven by drought and insect attack in recent decades (van Mantgem et al., 2009; Stephenson et al., 2019).

\section{Field sampling and growth.}

The field sites were distributed in or near networks of long-term forest monitoring plots located in intact, old-growth forests, including seven sites from van Mantgem et al. (2009) plus an eight site near Los Alamos, New Mexico (Breshears et al., 2009) (Table 1). Field sites were selected to cover a wide moisture gradient, from presumably temperature-limited sites in the temperate rainforests of the Pacific Northwest to presumably water-limited sites in the arid Southwest. We 
sampled the dominant tree species at each site, including: Hoh rainforest, Olympic National Park, WA (Picea sitchensis), Wind River Canopy Crane Site, WA (Pseudotsuga menziesii), HJ Andrews Experimental Forest, OR (Pseudotsuga menziesii), Rocky Mountain National Park, CO (Picea engelmannii), Sequoia National Park, CA (Pinus ponderosa), Sequoia National Park, CA (Abies concolor), Fraser Experimental Forest, CO (Pinus contorta), Los Alamos, NM (Pinus edulis). To facilitate comparison, we used three or four letters abbreviation to represent sampling site and four letters from tree species as site code: HOH PISI, WIND PSME, HJA PSME, ROMO PIEN, SEKI PIPO, SEKI ABCO, FRAS PICO, and LANL PIED (Table 1). At each site, we selected between five and eight dead trees with the following characteristics: standing and having died recently, as indicated by the presence of foliage and fine twigs and branches; being canopy dominant or co-dominant; receiving abundant light on their southern aspect; and having no evidence that the mortality was due to mechanical causes (as indicated by broken stems and tops). For each sampled dead tree, we then chose the closest nearby live tree that met the same criteria as the dead individual. In total, we sampled 98 trees across all sites (Table S1). For each tree, two tree cores were collected with a $12 \mathrm{~mm}$ diameter increment borer, generally at $1.37 \mathrm{~m}$ in height, but occasionally above or below this height if necessary to avoid wounds or defects in the trunk.

Cores were air dried and sanded with successively finer sandpaper prior to further analysis. Cores were cross dated visually using narrow marker years from tree-ring chronologies. For the surviving trees, the outer ring date was known, being the collection year (2009). Each ring was precisely cross-dated to its year of formation, using standard dendrochronological methods (Stokes \& Smiley, 1968). For the dead trees, we cross-dated it by comparing to the nearest living trees and assuming the year following the last tree-ring dated year was the year of tree death (Table S1). Surviving and dying trees had similar dated age but relatively low expressed population signal (EPS) at the site level (Table S1).

Raw basal area increment (BAI, $\mathrm{cm}^{2} \mathrm{yr}^{-1}$ ) was calculated from tree ring width measurements starting from the earliest ring in each core (the first full year of growth data) through the last year, along with diameter at breast height (corrected for phloem and bark thickness). Ring widths were converted to BAI using tree-specific circumferential growth (inside bark) and assuming concentric circularity as follows (McDowell et al., 2010):

This article is protected by copyright. All rights reserved 


$$
\mathrm{BAI}=\pi *\left(\mathrm{R}_{\mathrm{t}}^{2}-\mathrm{R}_{\mathrm{t}-1}^{2}\right)
$$

where $\mathrm{R}$ is trunk radius, $\mathrm{t}$ is the year of tree growth.

\section{Isotopic composition.}

After the increment cores had been cross-dated, we used one tree core from each tree to split annual rings using a scalpel under a dissecting scope. Because the last year of dying trees was different at each site, the timespan at different sites was not equal, but all tree cores were split from 1975 to include at least 25 years from the earliest year of death in the dying trees at each site for $\delta^{13} \mathrm{C}$. After reviewing the literature, we found that it was unnecessary to extract cellulose prior to measurement of $\delta^{13} \mathrm{C}$ because there was a consistent offset (on average 1.24\%o) between whole-wood and cellulose $\delta^{13} \mathrm{C}$ (Figure 1a). Additionally, there was no detectable effect of decomposition upon $\delta^{13} \mathrm{C}$ and $\delta^{18} \mathrm{O}$ within our samples (Figure 1c, d; English et al., 2011) We did not separate early from late-wood (Livingston \& Spittlehouse, 1996; Leavitt et al., 2002) because our objective was to examine the isotopes as a proxy for assimilation-weighted gas exchange characteristics at the crownscale along a complete growing season that the isotopes represent. Most cross-ring contamination is associated with carbon movement from the sapwood into the heartwood (S. Leavitt, personal communication) and all of our isotopic sample rings were located within the sapwood as estimated using the clear color difference between sapwood and heartwood. On rare occasions when the boundary was indistinguishable, the cores were not utilized. Each ring was individually diced and ground to a fine powder in a ball mill.

To extract $\alpha$-cellulose from wood for $\delta^{18} \mathrm{O}$ analysis we used the standard Brendel method modified for small samples (Brendel et al., 2000; Anchukaitis et al., 2008). Briefly, $800 \mu \mathrm{g}$ of ground wood tissue was placed in a $1.5 \mathrm{ml}$ centrifuge tube with screw on cap and silica gasket. We added 120 $\mu \mathrm{L} 80 \%$ acetic acid and $12 \mu \mathrm{L} \mathrm{69 \%} \mathrm{nitric} \mathrm{to} \mathrm{each} \mathrm{tube.} \mathrm{The} \mathrm{tubes} \mathrm{were} \mathrm{tightly} \mathrm{sealed} \mathrm{and} \mathrm{placed} \mathrm{in} \mathrm{an}$ aluminum heating block at $120^{\circ}\left( \pm 3^{\circ}\right)$ for 30 minutes. The tubes were then removed, allowed to cool and rinsed, centrifuged and decanted using ethanol, deionized water ( $>17.5 \mathrm{M} \Omega)$, ethanol again and finally acetone. The tubes were opened and left to dry in an oven at $70^{\circ}$ overnight and then placed in a vacuum desiccator until weighed out for isotopic analysis. The length of the tree-ring $\delta^{18} \mathrm{O}$ time series is shorter than that for $\delta^{13} \mathrm{C}$ because there was insufficient wood for $\alpha$-cellulose extraction at some 
sites, but we were able to ensure a consistent $\delta^{18} \mathrm{O}$ data record from at least six years prior to mortality per site.

The powder collected from each ring was analyzed on a CHN elemental analyzer (Costech Analytical Technologies, CA) and a Thermal Combustion Elemental Analyzer (Thermo Electron Corp, Waltham, MA), each attached to a continuous flow isotope ratio mass spectrometer (MAT 253, Thermo Electron Corp, Waltham, MA). Reported values are in per mil (\%) relative to V-PDB for $\delta^{13} \mathrm{C}$ analyses and $\mathrm{V}$-SMOW for $\delta^{18} \mathrm{O}$ analyses. The precision of our method based on means of laboratory standards (Aldrich $\sigma$-cellulose) for each analysis run was $0.07 \%$ for $\delta^{13} \mathrm{C}$ and $0.16 \%$ for $\delta^{18} \mathrm{O}$. An international standard (IAEA C3) run periodically yielded a mean value of $-24.91 \pm 0.05 \%$

for $\delta^{13} \mathrm{C}$ and $32.1 \pm 0.1 \%$ for $\delta^{18} \mathrm{O}$ ( \pm values are $95 \%$ confidence intervals). In this effort, we analyzed $1627 \delta^{13} \mathrm{C}$ samples and $508 \delta^{18} \mathrm{O}$ samples respectively, though the EPS of tree-ring width and $\delta^{13} \mathrm{C}$ series were mostly below 0.85 .

Tree-ring $\delta^{13} \mathrm{C}$ was converted to carbon isotope discrimination $\Delta$ (Farquhar \& Sharkey, 1982):

$$
\Delta=\frac{\delta^{13} \mathrm{C}_{\mathrm{a}}-\delta^{13} \mathrm{C}_{p}}{1+\delta^{13} \mathrm{C}_{p}}
$$

where $\delta^{13} \mathrm{C}_{\mathrm{a}}$ and $\delta^{13} \mathrm{C}_{\mathrm{p}}$ (in \%) are the carbon isotope compositions of the ambient air and tree rings, respectively. The $\delta^{13} \mathrm{C}_{\mathrm{a}}$ values since 1975 were derived from the observed values at Mauna Loa observatory. We assumed temporal variation of $\delta^{13} \mathrm{C}_{\mathrm{a}}$ among the eight sites were the same, and we used the same $\delta^{13} \mathrm{C}_{\mathrm{a}}$ data for the eight different sites.

$\Delta$ can also be expressed as the ratio of intercellular $\left(C_{\mathrm{i}}\right)$ and atmosphere $\left(C_{\mathrm{a}}\right) \mathrm{CO}_{2}$ concentration when post-photosynthetic fractionation processes are assumed to be negligible (but see Gessler et al., 2014):

$$
\Delta=a+(b-a) \times \frac{C_{\mathrm{i}}}{C_{\mathrm{a}}}
$$

where $a$ is the fractionation associated with diffusion in air (4.4\%), $b$ is the net fractionation associated with carboxylation by Rubisco (27\%). The atmospheric $\mathrm{CO}_{2}$ concentration since 1975 was

This article is protected by copyright. All rights reserved 
derived from direct measurements at the Mauna Loa observatory

(https://www.esrl.noaa.gov/gmd/ccgg/trends/data.html

The rates of carbon fixation $(A)$ and stomatal conductance $\left(\mathrm{g}_{\mathrm{s}}\right)$ are the primary factors

determining carbon isotopic discrimination, and thus the iWUE is related to $\Delta$ according to (Farquhar et al., 1982; Seibt et al., 2008),

$$
\mathrm{iWUE}=\frac{A}{g_{\mathrm{s}}}=\frac{C_{\mathrm{a}}-C_{\mathrm{i}}}{1.6}=\frac{C_{\mathrm{a}}\left(1-C_{\mathrm{i}} / C_{\mathrm{a}}\right)}{1.6}
$$

$\Delta$ provides an estimation of crown-scale gas-exchange, because tree-rings integrate assimilation weighted iWUE of the entire canopy.

\section{Climate data}

Not all sites had available climate data so gridded data (4 $\mathrm{km}$ resolution) were used for each site over the period 1975 to 2009. For each location we used monthly gridded mean temperature and monthly total precipitation, monthly VPD (averaged from monthly maximum and minimum VPD) data from the PRISM Climate Group (Di Luzio et al., 2008). For the analyses, we used annual average VPD through averaging the twelve months data.

\section{Analyses.}

To test for the difference between dying and living trees' growth across western USA, we calculated the annual growth ratio between dying and surviving trees (BAI dying $/ \mathrm{BAI}_{\text {surviving }}$ ) at each site, then, we averaged all sites into a temporal series prior to tree mortality (Cailleret et al., 2017). At each site, we analyzed the difference of dying and surviving tree growth, iWUE since 1975 and $\delta^{18} \mathrm{O}$ over last six years through paired $t$-test. The interannual variability in growth and isotopes were assessed using the coefficient of variation (CV) before tree mortality. For each tree, we calculated the CV during $1-5^{\text {th }}$ years, $6-10^{\text {th }}$ years, $11-15^{\text {th }}$ years, $16-20^{\text {th }}$ years and $21-25^{\text {th }}$ years before tree mortality, then averaged the $\mathrm{CV}$ from every individual dying and surviving trees. The $\mathrm{CV}$ is an index reflecting resilience in response to external stresses, e.g. drought (Zang et al., 2014; Cailleret et al., 2018). The difference of $\mathrm{CV}$ between dying and surviving trees for each five-year block was assessed using twofactor analysis of variance (ANOVA). Relationships of tree growth, $\Delta, \mathrm{iWUE}, \delta^{18} \mathrm{O}$ and VPD were calculated from linear regression. Covariance analysis was applied to identify the heterogeneity of 
slopes of iWUE vs $\delta^{18} \mathrm{O}$, VPD vs $\delta^{18} \mathrm{O}$, VPD vs iWUE between dying and surviving trees. We also used one-sample $t$ test to detect the difference of zero of dying and surviving tree growth, $\delta^{13} \mathrm{C}$, and $\delta^{18} \mathrm{O}$ in the conceptual framework. Statistical analyses were performed in SPSS 22.0 (IBM Corporation).

\section{Results}

We observed significantly lower BAI of dying trees compared to surviving trees across the western USA. BAI of dying trees in the year before mortality was only $56 \%$ of the BAI of surviving trees, and the duration of persistently lower radial growth was approximately three decades before tree mortality (Figure 2a). The dying trees sampled at seven of the eight sites had significantly ( $p<$ 0.05) lower radial growth than surviving trees since 1975 (Figure 3, Table S2). The single exception was Pinus contorta at Fraser experimental forest, Colorado, where BAI of dying trees exhibited significantly $(p<0.05)$ higher growth than surviving trees (Figure 3 ). At the remaining seven sites, the duration of lower radial growth prior to mortality exhibited large variability, ranging from 10 years to $>100$ years (Figure 3 ), however our results show no geographical pattern associated with the duration of lower radial growth across western USA.

There was a significant increasing trend of iWUE for both dying and surviving trees at all sites since 1975 (Figure 4). The increasing rate of iWUE at five of the eight sites was significantly smaller $(p<0.05)$ for dying trees compared to surviving trees. Averaged iWUE across all sites, the rate of iWUE increase in dying trees was significantly $(p<0.001)$ smaller than those of surviving trees, with $3.57 \mu \mathrm{mol} \mathrm{mol}^{-1}$ per decade in dying trees compared to $5.86 \mu \mathrm{mol} \mathrm{mol}^{-1}$ per decade in surviving trees (Fig. S2). Mean iWUE of dying trees was significantly greater $(p<0.05)$ than that of surviving trees at WIND PSME, HJA PSME, ROMO PIEN, while dying trees had lower iWUE values $(p<0.05)$ than surviving trees at HOH PISI, SEKI PIPO, LANL PIED (Table S2). There were no significant ( $p>$ 0.05 ) differences between dying and surviving iWUE for the two remaining sites (Table S2).

However, iWUE of dying trees during the last two years prior to mortality was significantly lower than that of surviving trees on average (Figure 2b).

For tree-ring $\delta^{18} \mathrm{O}$, there were no overall significant $(p>0.05)$ differences between dying and surviving trees observed prior to mortality (Figure 2c). Rings of dying trees had more positive $\delta^{18} \mathrm{O}$ at SEKI ABCO than of surviving trees but dying trees had more negative $\delta^{18} \mathrm{O}$ at WIND PSME and HJA 
PSME (Figure 5, Table S2). However, there was no difference between dying and surviving $\delta^{18} \mathrm{O}$ at the other five sites (HOH PISI, SEKI PIPO, ROMO PIEN, FRAS PICO, LANL PIED. Figure 5, Table S2).

Tree growth and stable isotopes exhibited different interannual variability between dying and surviving trees. We found dying trees had significantly greater CV of BAI than surviving trees over the last five years before tree mortality (Figure 6a). Specifically, the CV of BAI from dying trees increased significantly $(p<0.05)$ over the last five years relative to prior five-year time periods, whereas surviving trees' CV had changed little over time (Figure 6). For tree-ring $\Delta$ there was no CV differences at any five-year time periods between surviving and dying trees (Figure 6b). Regressions of normalized BAI vs. VPD at each site revealed that growth of dying trees at the five driest sites had significant negative relationships with evaporative water demand, in contrast to only two sites (one positive, one negative) for surviving trees (Fig. S3a). However, less clear relationships were observed in the dying and surviving $\Delta$ response to VPD (Fig. S3b).

In Figure $7 \mathrm{a}$ the long-term differences in growth and iWUE are plotted against each other, confirming that although over a 25 -year period reduced growth was detected in dying compared to surviving trees at seven out of eight sites, significantly greater $(p<0.05)$ in dying iWUE were detected at three sites (HJA PSME, WIND PSME, ROMO PIEN), while significantly lower $(p<0.05)$ in dying iWUE in the HOH PISI, LANL PIED site. When only the last five years before death are considered, dying trees exhibited a lower iWUE at four sites (Figure $7 \mathrm{~b}$ ). Tree-ring $\delta^{18} \mathrm{O}$, an additional proxy primary constrained by stomata (Giguère-Croteau et al., 2019; Guerrieri et al., 2019), reveals that more positive $\delta^{18} \mathrm{O}$ in dying trees at three of the four lower iWUE sites (HOH PISI, SEKI PIPO, LANL PIED), which indicates greater fractionation of leaf water by transpiration (Figure 7c; the "Scheidegger plot").

\section{Discussion}

Our study of eight old-growth forests revealed results that were consistent across sites (e.g. growth declines, Figure 3) and divergent across sites (e.g. isotopic signatures related to gas exchange, Figure 4). This suggests that a common process exists, as indicated by the lower growth of dying trees, yet the mechanisms leading to such lower growth may be diverse across our study sites. None of these sites had severe disturbances except FRAS PICO and LANL PIED (both of which experienced an 
insect outbreak), thus the increasing "background" mortality (e.g. mortality in the absence of physical disturbances) results potentially from drought and chronic atmospheric drivers such as rising VPD and $\mathrm{CO}_{2}$ (McDowell et al., 2020). Additionally, at some sites, particularly our wetter sites, declining growth of dying trees may have been associated with increasing competition and (or) ongoing attack by root pathogens or other biotic agents (Cherubini et al., 2002). Using the data within the conceptual model (Gessler et al., 2018) suggests the process of carbon starvation was relatively common across sites (Figure 7). We review the assumptions of these interpretations, and present alternative interpretations, through the discussion section.

The observation that dying trees have lower radial growth than their surviving congeners across western USA (Figure 3) is consistent with prior observations (Voltas et al., 2013; Williams et al., 2013; Camarero et al., 2015; Cailleret et al., 2017). Tree growth decline prior to mortality is expected, as dying trees (particularly under drought and a warming climate) are likely to have low photosynthetic rates due to stomatal closure (McDowell et al., 2016) or leaf loss (Poyatos et al., 2013) and less investment into radial growth (McDowell et al., 2010; Gessler et al., 2014). Low radial growth of dying trees may also be in part caused by relative reduction in allocation to above-ground growth (Mackay et al., 2020). Reduction of radial growth is symptomatic of carbon starvation, though it does not provide direct evidence of this physiological mechanism. Such direct evidence requires measurement of particularly low carbohydrate content in tree tissues prior to death (Dickman et al., 2015). Likewise, long periods of stomatal closure are also associated with prolonged cuticular loss of water and can lead to embolism of the vascular system and complete desiccation of the plant (MartinStPaul et al., 2017; Cochard, 2019), potentially co-occurring with carbon limitations. While some form of carbon limitation led to lower growth at seven of the eight sites, at FRAS PICO, in contrast, faster growing trees were attacked by mountain pine beetles (Dendroctonus ponderosae) that preferentially select larger hosts with thicker phloem (Raffa et al., 2008). Therefore, mountain pine beetles were the proximal or final cause of mortality at this site (Boone et al., 2011). While this occurred only in Pinus contorta in our study, this species is particularly widespread in North America (Coops \& Waring, 2011), thus such “overwhelming” of apparently healthy trees by mass beetle attack remains an important mechanism at the regional scale. Although dying trees have lower radial growth than their surviving at seven of the eight sites, it is noticeable at two sites (WIND PSME and LANL 
PIED) that dying trees experienced a slight growth increase prior to mortality. This phenomenon has been reported in other studies (Rowland et al., 2015; Cailleret et al., 2017), and indicates that hydraulic failure or insect outbreak, rather than carbon starvation, may drive the final mortality of trees. Ultimately, low radial growth of dying trees may be associated with both carbon starvation and hydraulic failure, as both mechanisms may be co-occurring in trees that die (Adams et al., 2017).

Comparing iWUE of dying and surviving trees potentially gives insight into past dynamics in $A$ and $g_{s}$ (Farquhar \& Sharkey, 1982; Gessler et al., 2014). In the current study, iWUE at six of the eight sites revealed differences between dying and surviving trees predominately in the last decade (Figure 4). One possible explanation is that dying trees have less capacity to adjust stomatal conductance (Martin-StPaul et al., 2017; Zadworny et al., 2019), or that they have larger cuticular conductance (Cochard, 2019). For the wettest site HOH PISI, there is lower iWUE of dying trees than that of surviving trees (Figure 4), which in a first interpretation would imply lower $A$ of dying trees but could also be related to higher $\mathrm{g}_{\mathrm{s}}$ (Farquhar et al., 1989; Cernusak et al., 2013; Poyatos et al., 2013). Lower $A$ of the dying trees may be associated with nutrient or light limitations (Craine et al., 2012; Gessler et al., 2017). Concerning $g_{s}$, it has been observed that stomatal conductance scales inversely with leaf area i.e., that trees with larger crowns have lower $\mathrm{g}_{\mathrm{s}}$ and vice versa (Mencuccini \& Comstock, 1999; Levanic et al., 2011) and thus higher $\mathrm{g}_{\mathrm{s}}$ might indicate significant foliage loss in the years before mortality as often observed with conifers (Dobbertin \& Brang, 2001; Poyatos et al., 2013).

The Scheidegger and Gessler approaches to partitioning carbon starvation and hydraulic failure (Scheidegger et al., 2000; Gessler et al., 2018) provide initial insight into mortality mechanisms (Figure 7). As reduced growth of dying trees might be associated with lower whole-tree carbon assimilation or more investment into the root system, no differences in mean iWUE for three sites either indicates that the ratio of $A$ to $g_{s}$ may have decreased at a similar rate prior to death or that there was in fact no change in $A$ and $\mathrm{g}_{\mathrm{s}}$ but that leaf area of the dying trees decreased (Cernusak et al., 2013; Poyatos et al., 2013). Considering only the last five years (Figure 7b), dying trees at four sites showed lower iWUE and three of those sites experienced $\delta^{18} \mathrm{O}$ enrichment (Figure 7c), which indicating reduced $A$ rather than increased $g_{s}$ may be responsible for the lower iWUE (Gessler et al., 2018). Constrained carbon uptake of those dying trees in HOH PISI, SEKI PIPO, LANL PIED 
suggests these sites most likely suffered from the carbon starvation process in the years before mortality (Gessler et al., 2018). These results confirmed that dying trees at three of the eight sites across western USA could be explained by the synchronic comparison tree growth and dual-isotope conceptual model, and the framework may facilitate to understand long-term tree mortality mechanisms.

Though the Scheidegger/Gessler approach provides initial insights into long-term physiological mechanisms, we acknowledge that there are at least four assumptions associated with Figure 7 that are possibly invalid, and thus lead to alternative interpretations of the dominance of carbon starvation and hydraulic failure upon the death process. Firstly, loss of leaf area such as due to defoliating pathogens or insects can influence the gas exchange (Whitehead, 1998) and hence interpretations from the isotopic results. Additionally, some tree species actively reduce their leaf area by leaf shedding and in the long term by reduced shoot growth (especially for conifers). Defoliation is likely an important factor for SEKI ABCO, where dying trees showed long-term growth reductions but no long-term change in iWUE, thus long-term reductions in leaf area with no noticeable effect on leaf level $\mathrm{A} / \mathrm{g}_{\mathrm{s}}$ would promote carbon starvation if the net, whole-tree photosynthesis is reduced below the carbon demand for survival.

Secondly, the challenge lies in the interpretation of the $\delta^{18} \mathrm{O}$ data, which is assumed within the approach to be representative of $g_{\mathrm{s}}$ (Scheidegger et al., 2000; Guerrieri et al., 2019). Differences in source water uptake can confound this interpretation. The $\delta^{18} \mathrm{O}$ result from SEKI ABCO was indeed more positive in the dying trees than the surviving trees, but with slight higher iWUE, which could thus be due to dying trees using shallower source water (Figure 7c). If dying trees fail to absorb water from deeper layers then a reduction in hydraulic conductance will manifest in reduced $g_{\mathrm{s}}$ and hence higher risk of both hydraulic failure and carbon starvation (Mackay et al., 2020).

Thirdly, by mechanistic resolution we mean the ability of tree-rings to record both carbon starvation and hydraulic failure is not equivalent i.e. the symptoms of carbon starvation (lower growth, shifts in iWUE) are recorded within tree-rings while the symptoms of hydraulic failure (xylem embolism, tissue dehydration) are not captured in current research. Thus, interpretation of Figure 7 for hydraulic failure relies in part on the absence of symptoms for carbon starvation (e.g. growth 
reduction). But growth reduction can co-occur with hydraulic failure, thus interpretation of the Scheidegger/Gessler approaches as evidence of carbon starvation does not exclude the process of hydraulic failure from occurring simultaneously. The same issue arises when we consider the temporal resolution of tree-ring data. Carbon starvation may be a dominant process over the long-term (inter-annual) record, but hydraulic failure may dominate the death process during the last months of life. In this situation, no evidence of hydraulic failure would emerge from the Scheidegger/Gessler approach even though it could be the dominant process during the final stages of death.

The last challenge to the Scheidegger/Gessler approach is that it excludes the potential for neither carbon starvation nor hydraulic failure to be the dominant death process. At FRAS PICO, for example, the overwhelming tree mortality by mass attack of aggressive outbreaking bark beetles was almost certainly much more important than either carbon starvation or hydraulic failure (Raffa et al., 2008), as Dendroctonus beetles during outbreaks often attack the most vigorous trees (Boone et al., 2011; de la Mata et al., 2017; Cooper et al., 2018). Hydraulic failure post-attack may occur, but would not be captured by our tree ring measurements because growth is unlikely during the late stages of attack and death. Insect attack is common during the death process in conifers of western USA (Raffa et al., 2008), and it is established that biotic agents, carbon starvation, and hydraulic failure can interact and feedback upon each other (Manion, 1981; McDowell et al., 2008; Gaylord et al., 2013), such that attack is more likely on trees weakened by carbon starvation and hydraulic failure, and likewise, after the pathogens have damaged the carbon and water supply and transport processes in the tree, the trees subsequently dies of rampant carbon starvation or hydraulic failure. This interactive process is not captured by the Gessler/Scheidegger approaches. Overall, multiple assumptions and uncertainties should be considered (Roden \& Siegwolf, 2012) when using the conceptual model to understand physiological mechanisms of tree mortality. The low consistency of tree growth and $\delta^{13} \mathrm{C}$ series among trees per site further confound the conceptual model results in our study, therefore large sample size would be suggested to assess physiological processes prior to tree mortality.

While direct or indirect effects of carbon starvation were implicated from the conceptual model to be important processes during death of these old-growth conifers in western USA, direct measurements of the degree of embolism and of non-structural carbohydrates are needed on dying and surviving trees to verify the dominant physiological mechanisms (McDowell \& Sevanto, 2010;

This article is protected by copyright. All rights reserved 
Sevanto et al., 2014). The apparent dominance of carbon starvation mechanisms observed from the conceptual approach in our study is consistent with other results from gymnosperms (Adams et al., 2017). As noted above, our study does not demonstrate a lack of hydraulic failure: our tree-ring measurements capture the long-term processes underlying mortality but do not capture short term processes that occur in the last months of life, during which time hydraulic failure may dominate. Thus, while these results suggest carbon starvation matters to the death of most western old-growth conifers, hydraulic failure may still play an important role.

Compared to surviving tree growth, dying trees' BAI were more sensitive to VPD (Fig. S3) suggesting that temperature-induced drought stress may have been a significant contributor to tree mortality (Adams et al., 2009; Allen et al., 2010; Williams et al., 2013). Increased VPD decreases conifer growth (Restaino et al., 2016), and is likely to promote further mortality of conifers in the future (Allen et al., 2015; McDowell et al., 2016). However, no differences in the tree-ring CV of carbon isotope discrimination between surviving and dying trees indicated that all trees may have similar year-to-year variation in $\Delta$ and cope with similar environmental stress. Trees that survive may have other strategies (e.g. varying depth of source water uptake, higher competitiveness for water, light and nutrient acquisition) to overcome the adverse effects of water deficiency (Barbeta \& Penuelas, 2017; McDowell et al., 2019).

\section{Conclusions}

Our retrospective dendroecological study revealed that dying conifer trees usually suffered substantially lower radial growth than surviving trees on a subcontinental scale and across diverse climate conditions. These lower radial growths were related to both stomatal and photosynthetic responses, reflected in the iWUE and $\delta^{18} \mathrm{O}$ variation of dying and surviving trees. In addition, we also found dying trees had lower ability to buffer external stress as shown by higher inter-annual CV during the last five years before tree mortality and greater sensitivity to VPD. From the conceptual model based on tree-ring proxies, direct or indirect effects (such as insect or pathogen attack) of carbon starvation were likely important contributors to tree mortality across western USA. However, indirect effects through insects and pathogens attack cannot be discerned from iWUE and $\delta^{18} \mathrm{O}$. At 
FRAS, we saw a dramatic example of this, where, in contrast to all other sites, dying trees were growing faster than living trees, almost certainly a consequence of host-tree selection by outbreaking bark beetles. Our results demonstrate that multi-proxy tree-ring records can yield important insights into the predisposition and physiological mechanisms of conifer mortality; however, the potential for alternative interpretations, such as strong co-occurrence of carbon starvation and hydraulic failure, remains plausible. We strongly recommend that future research should incorporate these methods with explicit identification of biotic mortality factors and direct observations of carbohydrates and hydraulic failure.

Acknowledgments: We appreciate the laboratory and field work carried out by student assistants Josh Bowman, Zach Breshears, Turin Dickman, Meghan Montoya, Kelsey Neal, Jaime Resnick, Kelly Steinberg, Elizabeth Stockton, and Samantha Stutz. This work was funded by the U.S. Geological Survey's Ecosystems mission area and Land Resources Research \& Development program, and by the Lab Directed Research and Development programs at LANL and at PNNL. WW is supported by the National Natural Science Foundation of China (41977396) and grateful for the support from the China Scholarship Council. Any use of trade, firm, or product names is for descriptive purposes only and does not imply endorsement by the U.S. Government.

\section{Authors' contributions}

NGM, AJD, NLS, and CDA conceived the ideas and designed this project; AJD and NLS conducted the fieldwork; CHB cross-dated and measured all of the increment cores for this study; NBE performed the sample preparation and stable isotope analysis; WW, CG, AG, NGM analysed the data; WW and NGM led the writing of the manuscript; all authors contributed critically to the drafts and gave final approval for publication.

This article is protected by copyright. All rights reserved 


\section{References}

Adams HD, Guardiola-Claramonte M, Barron-Gafford GA, Villegas JC, Breshears DD, Zou CB, Troch PA, Huxman TE. 2009. Temperature sensitivity of drought-induced tree mortality portends increased regional die-off under global-change-type drought. Proc Natl Acad Sci US A 106(17): 7063-7066.

Adams HD, Zeppel MJB, Anderegg WRL, Hartmann H, Landhausser SM, Tissue DT, Huxman TE, Hudson PJ, Franz TE, Allen CD, et al. 2017. A multi-species synthesis of physiological mechanisms in drought-induced tree mortality. Nat Ecol Evol 1(9): 1285-1291.

Allen CD, Breshears DD, McDowell NG. 2015. On underestimation of global vulnerability to tree mortality and forest die-off from hotter drought in the Anthropocene. Ecosphere 6(8): art129.

Allen CD, Macalady AK, Chenchouni H, Bachelet D, McDowell N, Vennetier M, Kitzberger T, Rigling A, Breshears DD, Hogg EH, et al. 2010. A global overview of drought and heatinduced tree mortality reveals emerging climate change risks for forests. Forest Ecology and Management 259(4): 660-684.

Anchukaitis KJ, Evans MN, Lange T, Smith DR, Leavitt SW, Schrag DP. 2008. Consequences of a rapid cellulose extraction technique for oxygen isotope and radiocarbon analyses. Anal Chem 80(6): 2035-2041.

Anderegg WR, Plavcova L, Anderegg LD, Hacke UG, Berry JA, Field CB. 2013. Drought's legacy: multiyear hydraulic deterioration underlies widespread aspen forest die-off and portends increased future risk. Glob Chang Biol 19(4): 1188-1196.

Anderegg WR, Schwalm C, Biondi F, Camarero JJ, Koch G, Litvak M, Ogle K, Shaw JD, Shevliakova E, Williams AP, et al. 2015. FOREST ECOLOGY. Pervasive drought legacies in forest ecosystems and their implications for carbon cycle models. Science 349(6247): 528532.

Ares A, Harrington CA, Terry TA, Kraft JM. 2008. Vegetation control effects on untreated wood, crude cellulose and holocellulose $\delta^{13} \mathrm{C}$ of early and latewood in 3- to 5-year-old rings of Douglas-fir. Trees 22(5): 603.

This article is protected by copyright. All rights reserved 
Barbeta A, Penuelas J. 2017. Increasing carbon discrimination rates and depth of water uptake favor the growth of Mediterranean evergreen trees in the ecotone with temperate deciduous forests. Glob Chang Biol 23(12): 5054-5068.

Barbour MM. 2007. Stable oxygen isotope composition of plant tissue: a review. Functional Plant Biology 34(2): 83-94.

Boone CK, Aukema BH, Bohlmann J, Carroll AL, Raffa KF. 2011. Efficacy of tree defense physiology varies with bark beetle population density: a basis for positive feedback in eruptive species. Canadian Journal of Forest Research-Revue Canadienne De Recherche Forestiere 41(6): 1174-1188.

Brendel O, Iannetta P, Stewart D. 2000. A rapid and simple method to isolate pure alpha-cellulose. Phytochemical Analysis: An International Journal of Plant Chemical and Biochemical Techniques 11(1): 7-10.

Breshears DD, Myers OB, Meyer CW, Barnes FJ, Zou CB, Allen CD, McDowell NG, Pockman WT. 2009. Tree die-off in response to global change-type drought: mortality insights from a decade of plant water potential measurements. Frontiers in Ecology and the Environment 7(4): 185-189.

Cailleret M, Dakos V, Jansen S, Robert EMR, Aakala T, Amoroso MM, Antos JA, Bigler C, Bugmann H, Caccianaga M, et al. 2018. Early-Warning Signals of Individual Tree Mortality Based on Annual Radial Growth. Front Plant Sci 9: 1964.

Cailleret M, Jansen S, Robert EM, Desoto L, Aakala T, Antos JA, Beikircher B, Bigler C, Bugmann H, Caccianiga M, et al. 2017. A synthesis of radial growth patterns preceding tree mortality. Glob Chang Biol 23(4): 1675-1690.

Camarero JJ, Gazol A, Sangüesa-Barreda G, Oliva J, Vicente-Serrano SM. 2015. To die or not to die: early warnings of tree dieback in response to a severe drought. Journal of Ecology 103(1): 44-57.

Cernusak LA, Ubierna N, Winter K, Holtum JA, Marshall JD, Farquhar GD. 2013. Environmental and physiological determinants of carbon isotope discrimination in terrestrial plants. New Phytol 200(4): 950-965.

This article is protected by copyright. All rights reserved 
Cherubini P, Fontana G, Rigling D, Dobbertin M, Brang P, Innes JL. 2002. Tree-life history prior to death: two fungal root pathogens affect tree-ring growth differently. Journal of Ecology 90(5): 839-850.

Choat B, Brodribb TJ, Brodersen CR, Duursma RA, Lopez R, Medlyn BE. 2018. Triggers of tree mortality under drought. Nature 558(7711): 531-539.

Christiansen E, Waring RH, Berryman AA. 1987. Resistance of Conifers to Bark Beetle Attack Searching for General Relationships. Forest Ecology and Management 22(1-2): 89-106.

Cochard H. 2019. A new mechanism for tree mortality due to drought and heatwaves. bioRxiv: 531632.

Colangelo M, Camarero JJ, Battipaglia G, Borghetti M, De Micco V, Gentilesca T, Ripullone F. 2017. A multi-proxy assessment of dieback causes in a Mediterranean oak species. Tree Physiol 37(5): 617-631.

Cooper LA, Reed CC, Ballantyne AP. 2018. Mountain pine beetle attack faster growing lodgepole pine at low elevations in western Montana, USA. Forest Ecology and Management 427: 200207.

Coops NC, Waring RH. 2011. A process-based approach to estimate lodgepole pine (Pinus contorta Dougl.) distribution in the Pacific Northwest under climate change. Climatic change 105(1-2): 313-328.

Craine JM, Engelbrecht BM, Lusk CH, McDowell NG, Poorter H. 2012. Resource limitation, tolerance, and the future of ecological plant classification. Front Plant Sci 3: 246.

Das AJ, Stephenson NL, Davis KP. 2016. Why do trees die? Characterizing the drivers of background tree mortality. Ecology 97(10): 2616-2627.

de la Mata R, Hood S, Sala A. 2017. Insect outbreak shifts the direction of selection from fast to slow growth rates in the long-lived conifer Pinus ponderosa. Proc Natl Acad Sci USA 114(28): 7391-7396.

Di Luzio M, Johnson GL, Daly C, Eischeid JK, Arnold JG. 2008. Constructing retrospective gridded daily precipitation and temperature datasets for the conterminous United States. Journal of Applied Meteorology and Climatology 47(2): 475-497.

This article is protected by copyright. All rights reserved 
Dickman LT, McDowell NG, Sevanto S, Pangle RE, Pockman WT. 2015. Carbohydrate dynamics and mortality in a pinon-juniper woodland under three future precipitation scenarios. Plant Cell Environ 38(4): 729-739.

Dobbertin M, Brang P. 2001. Crown defoliation improves tree mortality models. Forest Ecology and Management 141(3): 271-284.

Eglin T, Maunoury-Danger F, Fresneau C, Lelarge C, Pollet B, Lapierre C, Francois C, Damesin C. 2008. Biochemical composition is not the main factor influencing variability in carbon isotope composition of tree rings. Tree physiology 28(11): 1619-1628.

English NB, McDowell NG, Allen CD, Mora C. 2011. The effects of $\alpha$-cellulose extraction and blue-stain fungus on retrospective studies of carbon and oxygen isotope variation in live and dead trees. Rapid Communications in Mass Spectrometry 25(20): 3083-3090.

Farquhar GD, Ehleringer JR, Hubick KT. 1989. Carbon Isotope Discrimination and Photosynthesis. Annual Review of Plant Physiology and Plant Molecular Biology 40: 503-537.

Farquhar GD, Oleary MH, Berry JA. 1982. On the Relationship between Carbon Isotope Discrimination and the Inter-Cellular Carbon-Dioxide Concentration in Leaves. Australian Journal of Plant Physiology 9(2): 121-137.

Farquhar GD, Sharkey TD. 1982. Stomatal Conductance and Photosynthesis. Annual Review of Plant Physiology and Plant Molecular Biology 33(1): 317-345.

Gaylord ML, Kolb TE, McDowell NG. 2015. Mechanisms of pinon pine mortality after severe drought: a retrospective study of mature trees. Tree Physiol 35(8): 806-816.

Gaylord ML, Kolb TE, Pockman WT, Plaut JA, Yepez EA, Macalady AK, Pangle RE, McDowell NG. 2013. Drought predisposes piñon-juniper woodlands to insect attacks and mortality. New Phytologist 198(2): 567-578.

Gessler A, Cailleret M, Joseph J, Schonbeck L, Schaub M, Lehmann M, Treydte K, Rigling A, Timofeeva G, Saurer M. 2018. Drought induced tree mortality - a tree-ring isotope based conceptual model to assess mechanisms and predispositions. New Phytol 219(2): 485-490.

Gessler A, Ferrio JP, Hommel R, Treydte K, Werner RA, Monson RK. 2014. Stable isotopes in tree rings: towards a mechanistic understanding of isotope fractionation and mixing processes from the leaves to the wood. Tree Physiol 34(8): 796-818.

This article is protected by copyright. All rights reserved 
Gessler A, Low M, Heerdt C, de Beeck MO, Schumacher J, Grams TE, Bahnweg G, Ceulemans R, Werner H, Matyssek R, et al. 2009. Within-canopy and ozone fumigation effects on $\delta^{13} \mathrm{C}$ and $\delta^{18} \mathrm{O}$ in adult beech (Fagus sylvatica) trees: relation to meteorological and gas exchange parameters. Tree Physiol 29(11): 1349-1365.

Gessler A, Schaub M, McDowell NG. 2017. The role of nutrients in drought-induced tree mortality and recovery. New Phytol 214(2): 513-520.

Giguère-Croteau C, Boucher É, Bergeron Y, Girardin MP, Drobyshev I, Silva LCR, Hélie J-F, Garneau M. 2019. North America's oldest boreal trees are more efficient water users due to increased $\left[\mathrm{CO}_{2}\right]$, but do not grow faster. Proceedings of the National Academy of Sciences: 201816686.

Guerrieri R, Belmecheri S, Ollinger SV, Asbjornsen H, Jennings K, Xiao J, Stocker BD, Martin M, Hollinger DY, Bracho-Garrillo R, et al. 2019. Disentangling the role of photosynthesis and stomatal conductance on rising forest water-use efficiency. Proceedings of the National Academy of Sciences: 201905912.

Guerrieri R, Jennings K, Belmecheri S, Asbjornsen H, Ollinger S. 2017. Evaluating climate signal recorded in tree-ring $\delta^{13} \mathrm{C}$ and $\delta^{18} \mathrm{O}$ values from bulk wood and $\alpha$-cellulose for six species across four sites in the northeastern US. Rapid Communications in Mass Spectrometry 31(24): 2081-2091.

Harlow BA, Marshall JD, Robinson AP. 2006. A multi-species comparison of $\delta^{13} \mathrm{C}$ from whole wood, extractive-free wood and holocellulose. Tree physiology 26(6): 767-774.

Hartmann H, Moura CF, Anderegg WRL, Ruehr NK, Salmon Y, Allen CD, Arndt SK, Breshears DD, Davi H, Galbraith D, et al. 2018. Research frontiers for improving our understanding of drought-induced tree and forest mortality. New Phytol 218(1): 15-28.

Hentschel R, Rosner S, Kayler ZE, Andreassen K, Børja I, Solberg S, Tveito OE, Priesack E, Gessler A. 2014. Norway spruce physiological and anatomical predisposition to dieback. Forest Ecology and Management 322: 27-36.

Karl TR, Melillo JM, Peterson TC, Hassol SJ. 2009. Global climate change impacts in the United States: Cambridge University Press.

This article is protected by copyright. All rights reserved 
Leavitt SW, Wright WE, Long A. 2002. Spatial expression of ENSO, drought, and summer monsoon in seasonal $\delta^{13} \mathrm{C}$ of ponderosa pine tree rings in southern Arizona and New Mexico. Journal of Geophysical Research-Atmospheres 107(D18). 4349, doi:10.1029/2001JD001312.

Levanic T, Cater M, McDowell NG. 2011. Associations between growth, wood anatomy, carbon isotope discrimination and mortality in a Quercus robur forest. Tree Physiol 31(3): 298-308.

Livingston NJ, Spittlehouse DL. 1996. Carbon isotope fractionation in tree ring early and late wood in relation to intra-growing season water balance. Plant Cell and Environment 19(6): 768-774.

Loader NJ, Robertson I, McCarroll D. 2003. Comparison of stable carbon isotope ratios in the whole wood, cellulose and lignin of oak tree-rings. Palaeogeography Palaeoclimatology Palaeoecology 196(3-4): 395-407.

Macfarlane C, Warren CR, White DA, Adams MA. 1999. A rapid and simple method for processing wood to crude cellulose for analysis of stable carbon isotopes in tree rings. Tree physiology 19(12): 831.

Mackay DS, Savoy PR, Grossiord C, Tai X, Pleban JR, Wang DR, McDowell NG, Adams HD, Sperry JS. 2020. Conifers depend on established roots during drought: results from a coupled model of carbon allocation and hydraulics. New Phytol 225(2): 679-692.

Manion PD. 1981. Tree disease concepts, Upper Saddle River, NJ, USA: Prentice Hall.

Martin-StPaul N, Delzon S, Cochard H. 2017. Plant resistance to drought depends on timely stomatal closure. Ecol Lett 20(11): 1437-1447.

McCarroll D, Loader NJ. 2004. Stable isotopes in tree rings. Quaternary Science Reviews 23(7-8): 771-801.

McDowell NG, Allen CD, Anderson-Teixeira K, Aukema BH, Bond-Lamberty B, Chini L, Clark JS, Dietze M, Grossiord C, Hanbury-Brown A, et al. 2020. Pervasive shifts in forest dynamics in a changing world. Science 368(6494): eaaz9463.

McDowell NG, Allen CD, Anderson-Teixeira K, Brando P, Brienen R, Chambers J, Christoffersen B, Davies S, Doughty C, Duque A, et al. 2018. Drivers and mechanisms of tree mortality in moist tropical forests. New Phytol 219(3): 851-869.

This article is protected by copyright. All rights reserved 
McDowell NG, Allen CD, Marshall L. 2010. Growth, carbon-isotope discrimination, and droughtassociated mortality across a Pinus ponderosa elevational transect. Global Change Biology 16(1): 399-415.

McDowell NG, Beerling DJ, Breshears DD, Fisher RA, Raffa KF, Stitt M. 2011. The interdependence of mechanisms underlying climate-driven vegetation mortality. Trends Ecol Evol 26(10): 523-532.

McDowell NG, Grossiord C, Adams HD, Pinzón-Navarro S, Mackay DS, Breshears DD, Allen CD, Borrego I, Dickman LT, Collins A, et al. 2019. Mechanisms of a coniferous woodland persistence under drought and heat. Environmental Research Letters 14(4): 045014.

McDowell NG, Pockman WT, Allen CD, Breshears DD, Cobb N, Kolb T, Plaut J, Sperry J, West A, Williams DG, et al. 2008. Mechanisms of plant survival and mortality during drought: why do some plants survive while others succumb to drought? New Phytol 178(4): 719-739.

McDowell NG, Sevanto S. 2010. The mechanisms of carbon starvation: how, when, or does it even occur at all? New Phytol 186(2): 264-266.

McDowell NG, Williams AP, Xu C, Pockman WT, Dickman LT, Sevanto S, Pangle R, Limousin J, Plaut J, Mackay DS, et al. 2016. Multi-scale predictions of massive conifer mortality due to chronic temperature rise. Nature Clim. Change 6(3): 295-300.

Mencuccini M, Comstock J. 1999. Variability in hydraulic architecture and gas exchange of common bean (Phaseolus vulgaris) cultivars under well-watered conditions: interactions with leaf size. Functional Plant Biology 26(2): 115-124.

Poyatos R, Aguadé D, Galiano L, Mencuccini M, Martínez-Vilalta J. 2013. Drought-induced defoliation and long periods of near-zero gas exchange play a key role in accentuating metabolic decline of Scots pine. New Phytologist 200(2): 388-401.

Raffa KF, Aukema BH, Bentz BJ, Carroll AL, Hicke JA, Turner MG, Romme WH. 2008. Cross-scale drivers of natural disturbances prone to anthropogenic amplification: The dynamics of bark beetle eruptions. Bioscience 58(6): 501-517.

Restaino CM, Peterson DL, Littell J. 2016. Increased water deficit decreases Douglas fir growth throughout western US forests. Proc Natl Acad Sci US A 113(34): 9557-9562.

This article is protected by copyright. All rights reserved 
Roden JS, Lin GG, Ehleringer JR. 2000. A mechanistic model for interpretation of hydrogen and oxygen isotope ratios in tree-ring cellulose. Geochimica et Cosmochimica Acta 64(1): 21-35.

Roden JS, Siegwolf R. 2012. Is the dual-isotope conceptual model fully operational? Tree Physiol 32(10): 1179-1182.

Rowland L, da Costa AC, Galbraith DR, Oliveira RS, Binks OJ, Oliveira AA, Pullen AM, Doughty CE, Metcalfe DB, Vasconcelos SS, et al. 2015. Death from drought in tropical forests is triggered by hydraulics not carbon starvation. Nature 528(7580): 119-122.

Scheidegger Y, Saurer M, Bahn M, Siegwolf R. 2000. Linking stable oxygen and carbon isotopes with stomatal conductance and photosynthetic capacity: a conceptual model. Oecologia 125(3): 350-357.

Schleser GH, Anhuf D, Helle G, Vos H. 2015. A remarkable relationship of the stable carbon isotopic compositions of wood and cellulose in tree-rings of the tropical species Cariniana micrantha (Ducke) from Brazil. Chemical Geology 401: 59-66.

Seibt U, Rajabi A, Griffiths H, Berry JA. 2008. Carbon isotopes and water use efficiency: sense and sensitivity. Oecologia 155(3): 441-454.

Sevanto S, McDowell NG, Dickman LT, Pangle R, Pockman WT. 2014. How do trees die? A test of the hydraulic failure and carbon starvation hypotheses. Plant Cell Environ 37(1): 153-161.

Stephenson NL, Das AJ, Ampersee NJ, Bulaon BM, Yee JL, Edwards D. 2019. Which trees die during drought? The key role of insect host-tree selection. Journal of Ecology 107(5): 23832401.

Stokes MA, Smiley TL. 1968. An Introduction to Tree Ring Dating. Chicago: the University of Chicago Press.

Szymczak S, Joachimski MM, Bräuning A, Hetzer T, Kuhlemann J. 2011. Comparison of whole wood and cellulose carbon and oxygen isotope series from Pinus nigra ssp. laricio (Corsica/France). Dendrochronologia 29(4): 219-226.

Taylor AM, Renée Brooks J, Lachenbruch B, Morrell JJ, Voelker S. 2008. Correlation of carbon isotope ratios in the cellulose and wood extractives of Douglas-fir. Dendrochronologia 26(2): 125-131.

This article is protected by copyright. All rights reserved 
van Mantgem PJ, Stephenson NL, Byrne JC, Daniels LD, Franklin JF, Fule PZ, Harmon ME, Larson AJ, Smith JM, Taylor AH, et al. 2009. Widespread increase of tree mortality rates in the western United States. Science 323(5913): 521-524.

Verheyden A, Roggeman M, Bouillon S, Elskens M, Beeckman H, Koedam N. 2005. Comparison between $\delta^{13} \mathrm{C}$ of $\alpha$-cellulose and bulk wood in the mangrove tree Rhizophora mucronata: Implications for dendrochemistry. Chemical Geology 219(1): 275-282.

Verlinden MS, Fichot R, Broeckx LS, Vanholme B, Boerjan W, Ceulemans R. 2015. Carbon isotope compositions $\left(\delta^{13} \mathrm{C}\right)$ of leaf, wood and holocellulose differ among genotypes of poplar and between previous land uses in a short-rotation biomass plantation. Plant, Cell \& Environment 38(1): 144-156.

Voltas J, Camarero JJ, Carulla D, Aguilera M, Ortiz A, Ferrio JP. 2013. A retrospective, dualisotope approach reveals individual predispositions to winter-drought induced tree dieback in the southernmost distribution limit of Scots pine. Plant Cell Environ 36(8): 1435-1448.

Waring RH. 1987. Characteristics of Trees Predisposed to Die. Bioscience 37(8): 569-574.

Weigt RB, Bräunlich S, Zimmermann L, Saurer M, Grams TEE, Dietrich H-P, Siegwolf RTW, Nikolova PS. 2015. Comparison of $\delta^{18} \mathrm{O}$ and $\delta^{13} \mathrm{C}$ values between tree-ring whole wood and cellulose in five species growing under two different site conditions. Rapid Communications in Mass Spectrometry 29(23): 2233-2244.

Whitehead D. 1998. Regulation of stomatal conductance and transpiration in forest canopies. Tree physiology 18(8-9): 633-644.

Williams AP, Allen CD, Macalady AK, Griffin D, Woodhouse CA, Meko DM, Swetnam TW, Rauscher SA, Seager R, Grissino-Mayer HD, et al. 2013. Temperature as a potent driver of regional forest drought stress and tree mortality. Nature Climate Change 3(3): 292-297.

Zadworny M, Jagodziński AM, Lakomy P, Mucha J, Oleksyn J, Rodríguez-Calcerrada J, Ufnalski K. 2019. Regeneration origin affects radial growth patterns preceding oak decline and death-insights from tree-ring $\delta^{13} \mathrm{C}$ and $\delta^{18} \mathrm{O}$. Agricultural and Forest Meteorology 278: 107685.

This article is protected by copyright. All rights reserved 
Zang C, Hartl-Meier C, Dittmar C, Rothe A, Menzel A. 2014. Patterns of drought tolerance in major European temperate forest trees: climatic drivers and levels of variability. Glob Chang Biol 20(12): 3767-3779.

This article is protected by copyright. All rights reserved 
Supporting information:

Fig. S1. Sampling locations across western USA.

Fig. S2. Dying and surviving tree's intrinsic water-use efficiency (iWUE) variation over time.

Fig. S3. Tree growth and $\Delta$ response to growing season VPD.

Table S1. Information about sampling trees and characteristics of the cross-dating information.

Table S2. Paired $t$ test results of dying and surviving tree growth (BAI), iWUE, and $\delta 18 \mathrm{O}$ series since 1975 across eight sites in western USA.

Table 1. Tree species, geographical and climate information at the eight sampling sites across western USA.

\begin{tabular}{ccccccc}
\hline \multirow{2}{*}{ Site code } & Species & $\begin{array}{c}\text { Latitude } \\
(\mathbf{N})\end{array}$ & $\begin{array}{c}\text { Longitude } \\
(\mathbf{W})\end{array}$ & $\begin{array}{c}\text { Altitude } \\
(\mathbf{m})\end{array}$ & $\begin{array}{c}\text { Temperature } \\
\left({ }^{\circ} \mathbf{C}\right)\end{array}$ & $\begin{array}{c}\text { Precipitation } \\
(\mathbf{m m})\end{array}$ \\
\hline HOH PISI & Picea sitchensis & $47^{\circ} 46^{\prime}$ & $123^{\circ} 58^{\prime}$ & 710.5 & 8.3 & 3988.4 \\
WIND PSME & Pseudotsuga menziesii & $45^{\circ} 48^{\prime}$ & $121^{\circ} 57^{\prime}$ & 641.9 & 8.6 & 2533.7 \\
HJA PSME & Pseudotsuga menziesii & $44^{\circ} 14^{\prime}$ & $12^{\circ} 11^{\prime}$ & 732.7 & 9.1 & 2139.0 \\
ROMO PIEN & Picea engelmannii & $40^{\circ} 18^{\prime}$ & $105^{\circ} 37^{\prime}$ & 3025.4 & 0.9 & 1045.7 \\
SEKI PIPO & Pinus ponderosa & $36^{\circ} 33^{\prime}$ & $118^{\circ} 45^{\prime}$ & 1966.3 & 11.3 & 944.9 \\
SEKI ABCO & Abies concolor & $36^{\circ} 33^{\prime}$ & $118^{\circ} 45^{\prime}$ & 1966.6 & 11.3 & 944.9 \\
FRAS PICO & Pinus contorta & $39^{\circ} 53^{\prime}$ & $105^{\circ} 54^{\prime}$ & 2944.4 & 1.5 & 625.0 \\
LANL PIED & Pinus edulis & $35^{\circ} 51^{\prime}$ & $106^{\circ} 17^{\prime}$ & 2161.0 & 9.9 & 461.2
\end{tabular}

Annual mean temperature and total precipitation were averaged during the period 1975-2009.

This article is protected by copyright. All rights reserved 


\section{Figures}

Figure 1. Sampling and processing impacts on isotopic results. Regressions of (a) $a$-cellulose and whole wood $\delta^{13} \mathrm{C}$ from multiple published studies (Macfarlane et al., 1999; Loader et al., 2003; Verheyden et al., 2005; Harlow et al., 2006; Ares et al., 2008; Eglin et al., 2008; Taylor et al., 2008; English et al., 2011; Szymczak et al., 2011; Schleser et al., 2015; Verlinden et al., 2015; Weigt et al., 2015; Guerrieri et al., 2017), (b) a-cellulose and whole wood $\delta^{18} \mathrm{O}$ from four previous studies (English et al., 2011; Szymczak et al., 2011; Weigt et al., 2015; Guerrieri et al., 2017), (c) live and dead whole wood $\delta^{13} \mathrm{C}$ (English et al., 2011), and (d) live and dead $a$-cellulose $\delta^{18} \mathrm{O}$ from our study species and sites (English et al., 2011). All panels include data from English et al. (2011), in which the samples originated from the same trees as those in the current manuscript.

\section{Figure 2. Temporals of dying and surviving trees' growth, iWUE and $\delta^{18} O$ across western USA.} (a) Growth ratio (basal area increment $(\mathrm{BAI}), \mathrm{BAI}_{\text {dying }} / \mathrm{BAI}_{\text {surviving }}$ ) of dying and surviving trees from eight conifer sites during the last 100 years before tree mortality; (b) the difference between dying and surviving trees' intrinsic water-use efficiency (iWUE) from eight conifer sites during the last 32 years before tree mortality; (c) difference of dying and surviving tree-ring $\delta^{18} \mathrm{O}$ from the eight conifer sites during the last seven years prior to tree mortality. Error bars in each panel are $\pm 1 \mathrm{SE}$ among sites. Dashed lines at each panel represent no difference of dying and surviving trees.

Figure 3. Long-term site-level mean basal area increment (BAI) variation for dying and surviving trees at the eight sites across western USA. The sites are organized from wettest to driest (see supporting information Fig. S1). No error bars are shown to improve clarity.

\section{Figure 4. Intrinsic water-use efficiency (iWUE) of dying and surviving trees at the eight sites} across western USA (see supporting information Fig. S1). The slopes \pm SE (black text is surviving 
trees; red text is dying trees) and $\mathrm{R}^{2}$ of each individual series are shown. Error bars at each panel are $\pm 1 \mathrm{SE}$ among trees.

Figure 5. Tree-ring $\delta^{18} \mathrm{O}$ variations of dying and surviving trees at the eight sites across western USA. The sites are organized from wettest to driest (see supporting information Fig. S1). Error bars in each panel are $\pm 1 \mathrm{SE}$ among trees.

Figure 6. Tree growth and $\Delta$ variability before mortality across the western USA. Coefficient of variation for all individual (a) basal area increment (BAI), (b) $\Delta$ at each 5-yrs block before tree mortality. Error bar represent $\pm 1 \mathrm{SE} . *: p<0.05, * *: p<0.01$.

\section{Figure 7. Ratios of growth and isotopic composition between dying and surviving trees on}

different time scales. (a) and (b) shows the growth and intrinsic water-use efficiency (iWUE) ratios in four quadrants indicating a history of reduced growth and increased iWUE (upper left), reduced growth and decreased iWUE (lower left), increased growth and increased iWUE (upper right), and increased growth and decreased iWUE (lower right) of dying trees. (a) comprises long-term information of the last 25 years before mortality (excluding the last five years before mortality) and (b) includes only the last five years before mortality. In (c) ratios in iWUE and $\delta^{18} \mathrm{O}$ for the last five years. Error bars are SE of time period. The relative dominance of carbon starvation (CS) and hydraulic failure (HF) are labeled within the figures according to the concept framework of Gessler et al. (2018). Site locations see supporting information Fig. S1. 

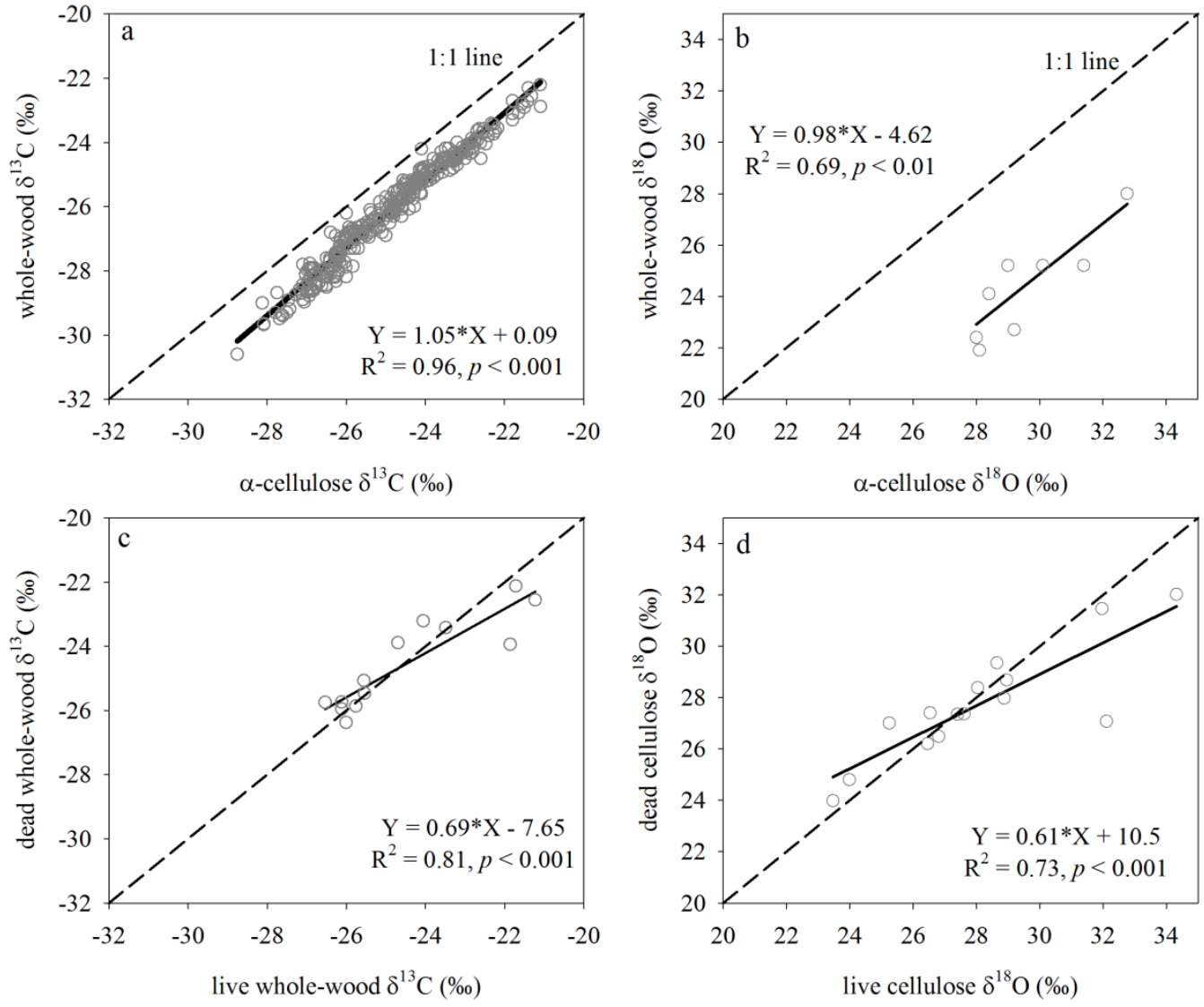

nph_16864_f1.tif

This article is protected by copyright. All rights reserved 

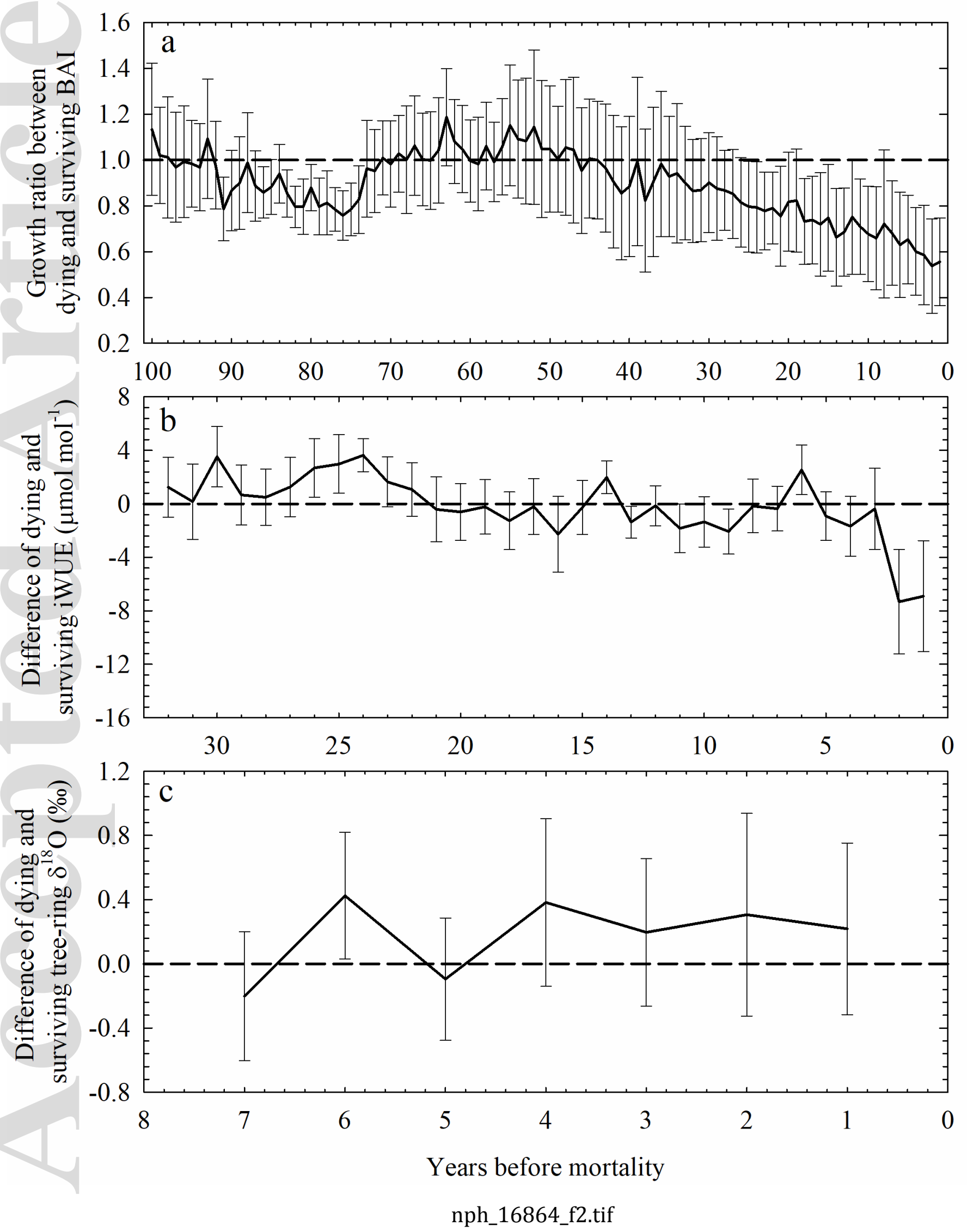

This article is protected by copyright. All rights reserved 

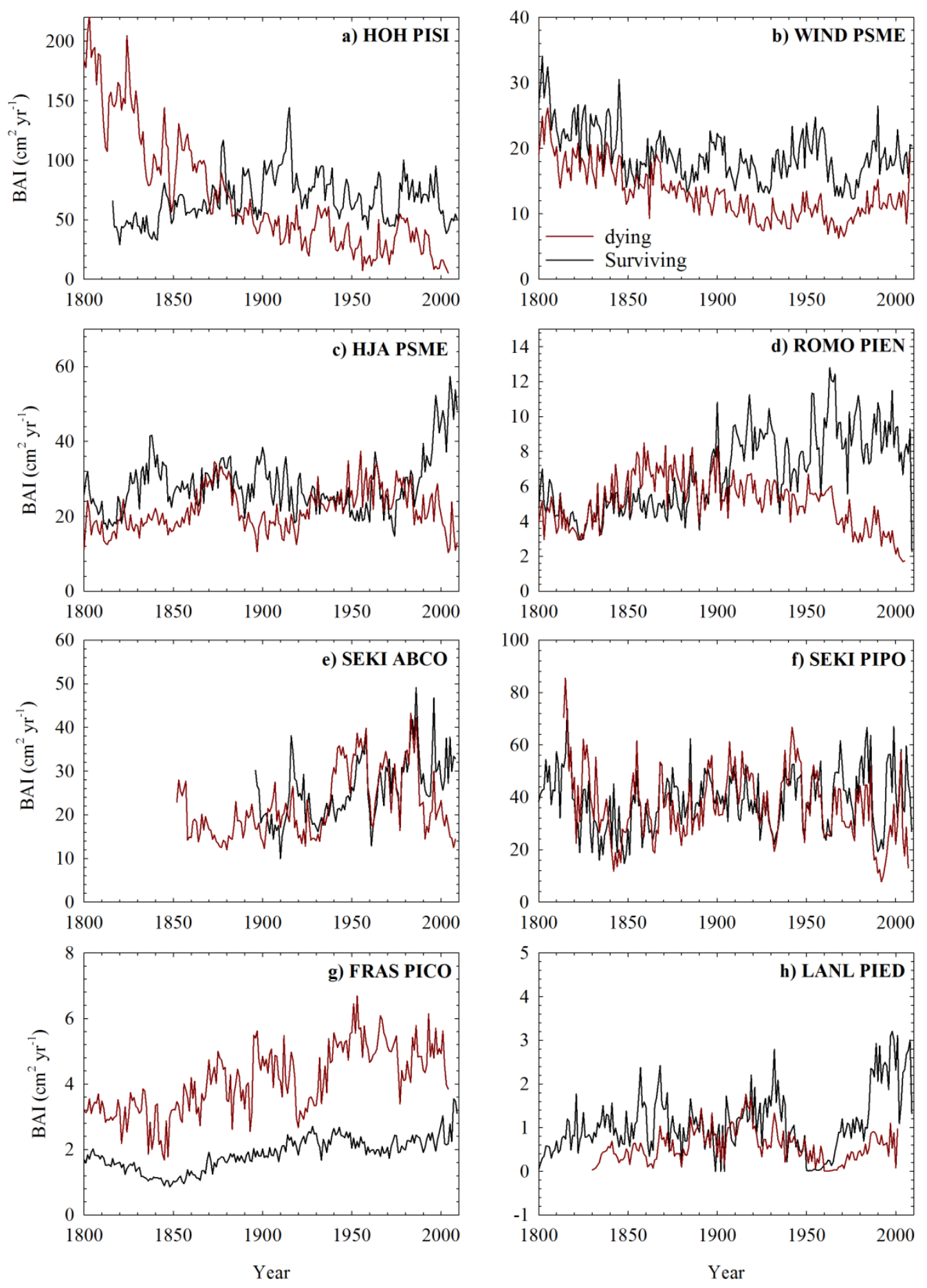

nph_16864_f3.tif

This article is protected by copyright. All rights reserved 

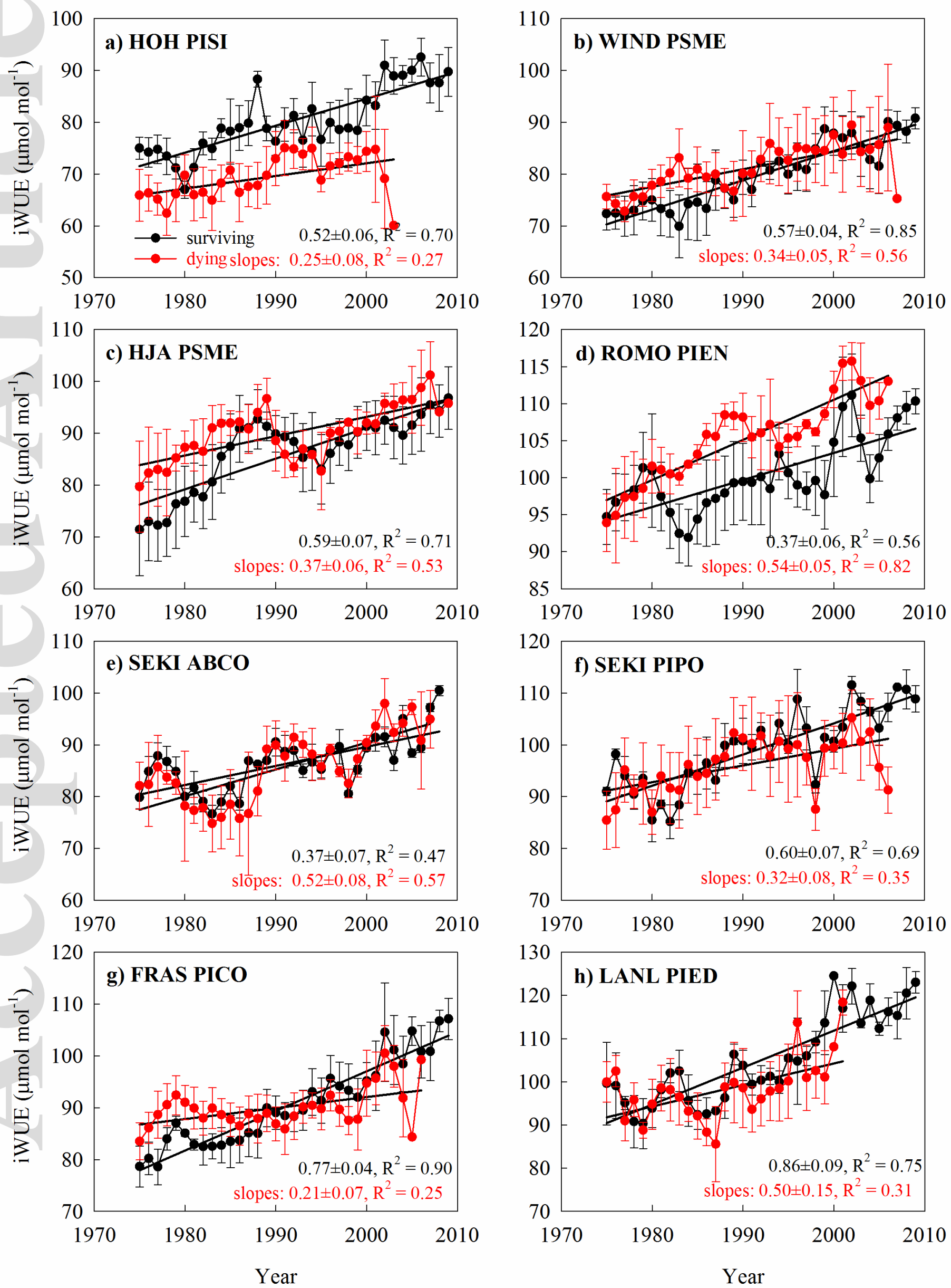

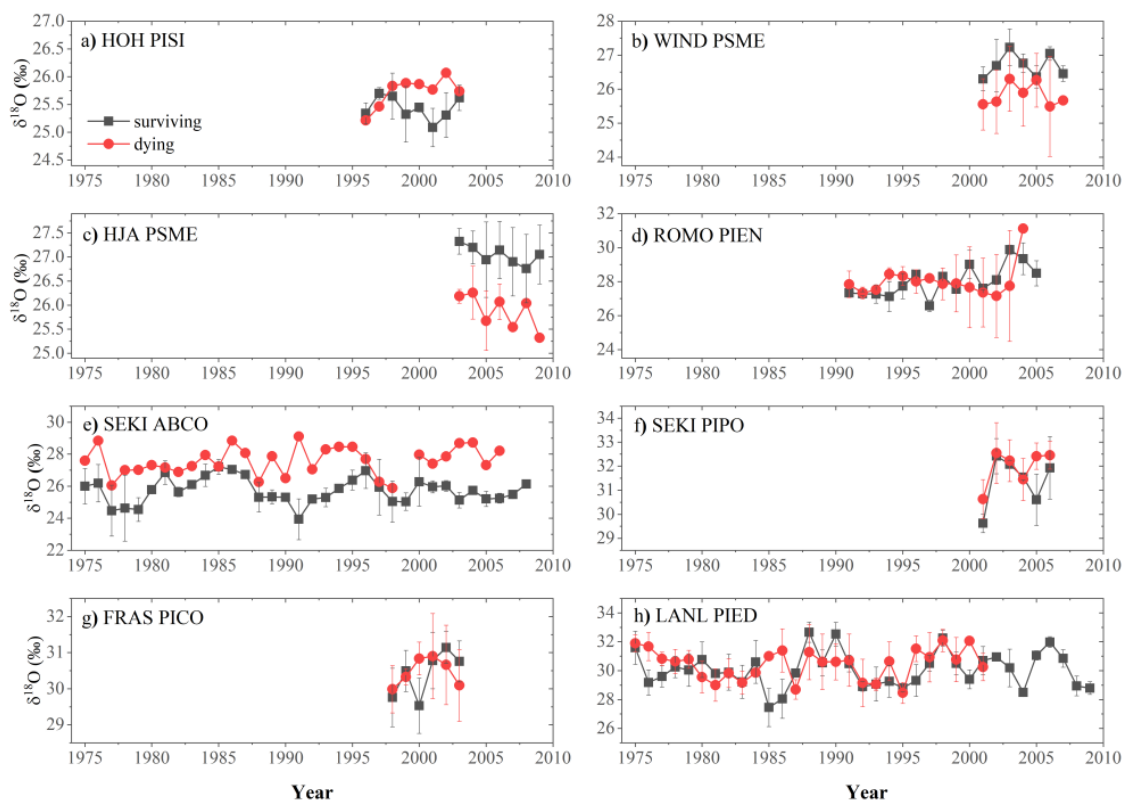

nph_16864_f5.tif 

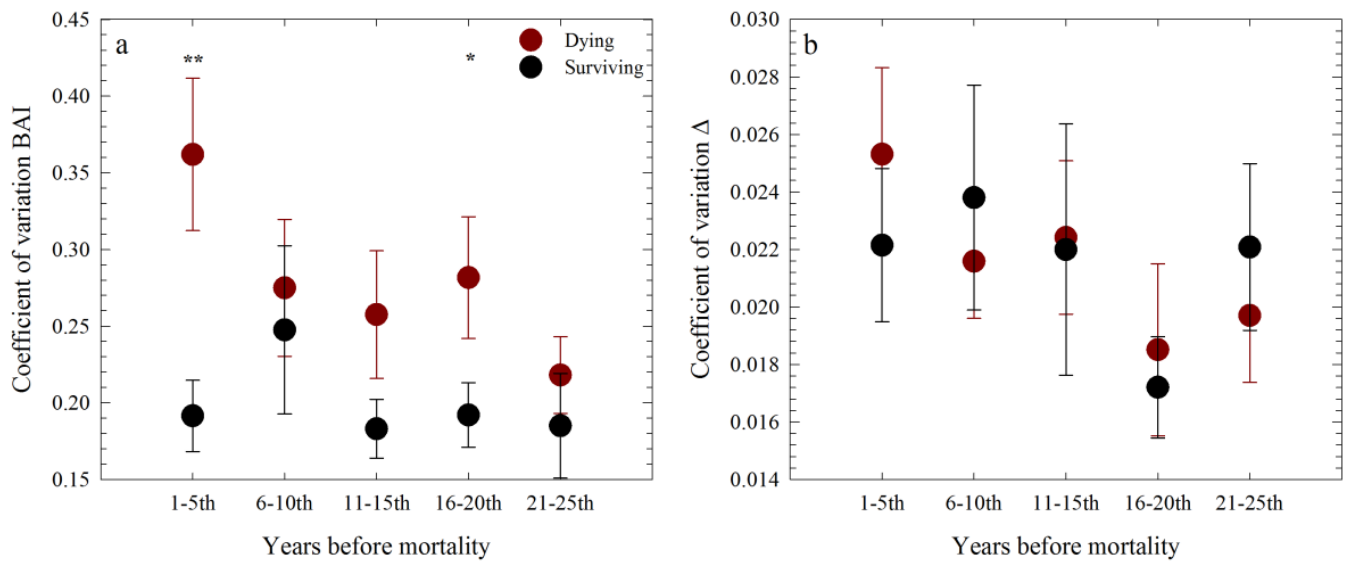

nph_16864_f6.tif

This article is protected by copyright. All rights reserved 

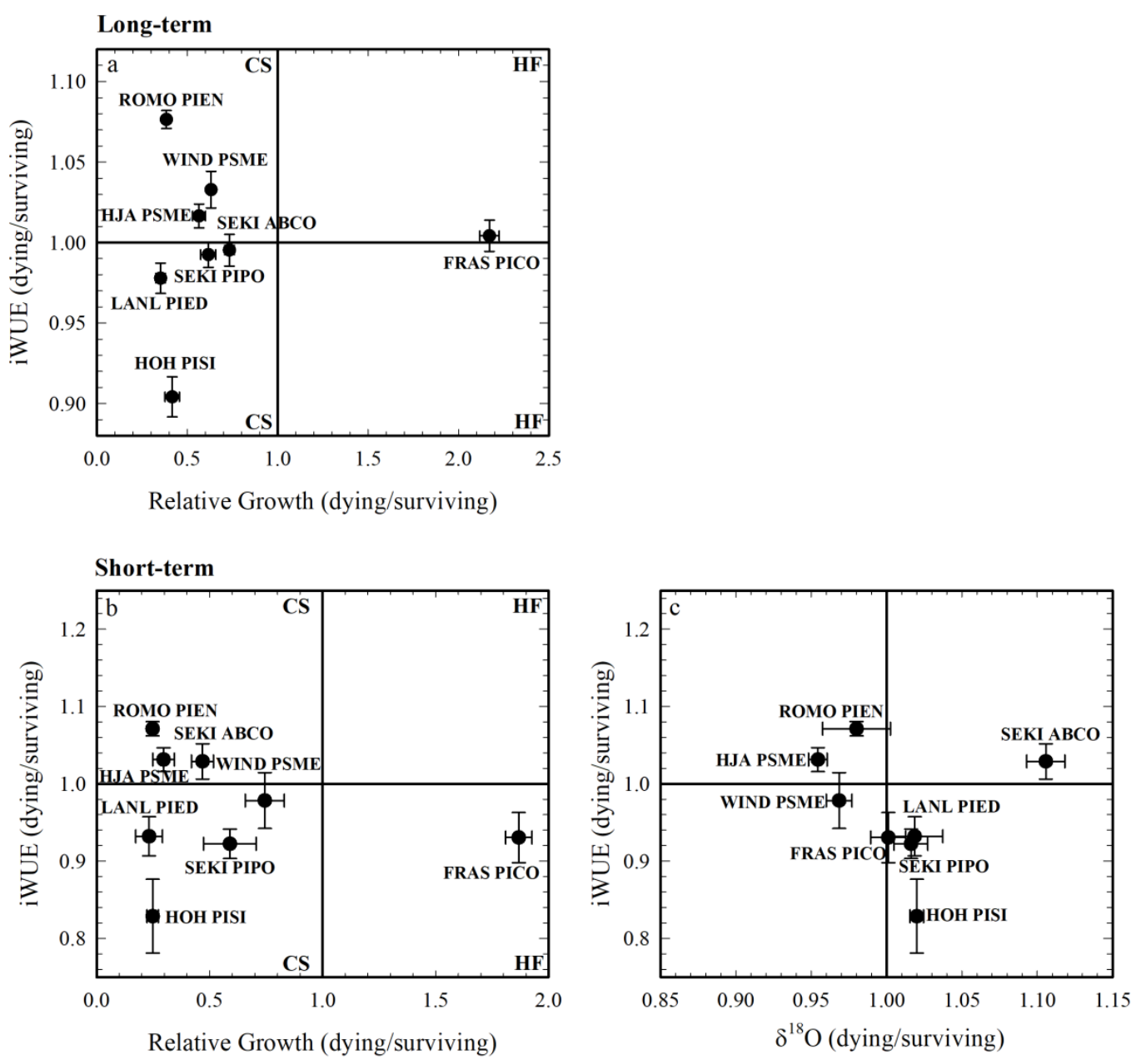

nph_16864_f7.tif 